\title{
FAKTOR-FAKTOR PENYEBAB RENDAHNYA EFIKASI DIRI SISWA
}

Oleh:

\author{
Fitriani' $^{1)}$, Abas Rudin ${ }^{2)}$ \\ 1) 2) Jurusan Bimbingan dan Konseling \\ Fakultas Keguruan dan Ilmu Pendidikan, Universitas Halu Oleo \\ Email: ${ }^{1)}$ fitriani123456789fit@gmail.com ${ }^{2)}$ abasrudin2@ gmail.com
}

\begin{abstract}
ABSTRAK
Penelitian ini bertujuan untuk mengetahui Faktor-Faktor Penyebab Rendahnya Efikasi diri Siswa SMP Negeri 3 Sampolawa. Penelitian ini adalah Penelitian kualitatif dengan jenis penelitian studi kasus. Informan dari penelitian ini berjumlah 4 orang. 1 orang guru, 1 orang Wali Kelas, dan 2 orang siswa. Data dikumpulkan menggunakan metode wawancara dan studi dokumentasi. Metode Analisis data menggunakan metode analisis deskriptif kualitatif model Miles dan Hubberman. Hasil Penelitian ini menunjukan bahwa faktor-faktor penyebab rendahnya efikasi diri siswa adalah: faktor pengalaman menguasai sesuatu, faktor modeling sosial, faktor persuasi sosial, faktor kondisi fisik dan emosional, faktor budaya, faktor jenis kelamin, faktor dari tugas yang dihadapi dan faktor insentif eksternal.
\end{abstract}

Kata Kunci: Efikasi diri

\section{FACTORS CAUSING STUDENTS LOW SELF EFICATION}

\begin{abstract}
This study aims to determine the causes of low self-efficacy of SMP Negeri 3 Sampolawa Students. This is qualitative research with a type of case study. The informants were 4 people. 1 teacher, 1 homeroom teacher, and 2 students. Data was collected using data interview methods and documentation. Data analysis used the qualitative descriptive analysis method of Miles and Huberman models. The results of this study indicate that the factors that cause low self-efficacy of students are: mastering things factors, social modeling factors, social persuasion factors, physical and emotional factors, cultural factors, gender factors, factors of tasks faced and incentive external factors.
\end{abstract}

Keywords: Self Efficacy 


\section{Pendahuluan}

Dalam lingkungan sekolah terjadi berbagai macam interaksi antara siswa. Interaksi yang terjadi antara siswa di lingkungan sekolah akan membawa dampak negatif dan dampak positif bagi perkembangan siswa. Interaksi yang terus menerus terjadi ini akan memengaruhi pembentukan perilaku siswa dimana dalam dunia pendidikan terdapat berbagai macam perilaku yang dimiliki oleh setiap peserta didik, baik perilaku positif dan perilaku negatif.

Perilaku positif tidak akan menimbulkan dampak buruk bagi diri siswa dan menghambat perkembangannya. Tetapi lain halnya dengan perilaku negatif siswa. Perilaku negatif siswa akan memengaruhi perkembangan siswa dan memberikan dampak yang buruk terhadap diri siswa sendiri dan orang-orang sekitarnya sehingga siswa harus mampu menghindari perilaku-perilaku negatif tersebut. seperti perilaku-perilaku yang paling menonjol atau yang sering terjadi di SMP Negeri 3 Sampolawa adalah persoalan efikasi diri.

Efikasi diri merupakan salah satu aspek pengetahuan tentang diri atau self knowladge. Yang paling berpengaruh dalam kehidupan manusia sehari-hari. Hal ini disebabkan efikasi diri yang dimiliki ikut memengaruhi individu dalam menentukan tindakan yang akan dilakukan untuk mencapai tujuan, termasuk di dalamnya perkiraan berbagai kejadian yang akan dicapai. Efikasi diri siswa adalah kepercayaan siswa untuk menentukan bagaimana dia merasa, berfikir, memotivasi dan berprilaku. Kemudian siswa percaya akan kemampuannya untuk meningkatkan prestasi setelah diberikan pekerjaan serta peristiwa yang memengaruhi kehidupannya. Kepercayaan ini akan menghasilkan beragam efek melalui empat proses besar, yaitu; kognitif, motivasi, afektif dan proses pemilihan tindakan. Pemilihan tindakan yang dimaksud adalah hal yang akan dilakukan setelah mengikuti pembelajaran.

Taylor (dalam Rokhimah, 2015: 386) mengatakan bahwa efikasi diri yaitu ekspetasi spesifik yang kita yakini tentang kemampuan kita dalam mencapai sesuatu atau mengerjakan tugas. Sesuai dengan pendapat yang dikemukakan oleh Adicondro dan Alfi (2011) yang mengatakan jika seseorang memiliki efikasi diri yang tinggi maka dia akan memiliki keyakinan mengenai kemampuannya dalam mengorganisasi dan menyelesaikan suatu tugas yang diperlukan untuk mencapai hasil tertetu dalam berbagai bentuk dan tingkat kesulitan. Sebaliknya jika seseorang dengan efikasi diri yang rendah akan sangat memengaruhi seseorang dalam menyelesaikan tugasnya untuk mencapai hasil tertentu.

Rustika (2012: 18) menyebutkan bahwa efikasi memegang peran yang sangat penting dalam kehidupan sehari-hari, seseorang akan mampu menggunakan potensi dirinya secara optimal apabila efikasi diri mendukungnya. Efikasi diri tidak datang dengan sendirinya, tetapi merupakan hasil dari berbagi pengetahuan dan tanggung jawab, hubungan yang beragam, tugastugas yang bermanfaat dan interaksi dengan orang lain.

Bandura (dalam Ghufron dan Rini 2014: 80) menyebutkan bahwa efikasi diri pada diri individu akan berbeda antara satu individu dengan individu yang lainya. Efikasi diri sangat menentukan seberapa besar keyakinan mengenai kemampuan yang dimiliki oleh setiap individu untuk melakukan proses belajarnya sehingga dapat mencapai hasil belajar yang optimal. Individu yang memiliki efikasi diri yang tinggi akan dengan baik mengatur dirinya untuk belajar, karena ada keyakinan dalam dirinya bahwa ia akan mampu menyelesaikan tugas sesulit apapun saat belajar, keyakinan bahwa ia mampu menyelesaikan berbagai macam tugas serta usaha yang keras untuk menyelesaikan semua tugas.

Siswa yang memiliki efikasi diri yang tinggi akan lebih optimis, pantang menyerah dan akan memengaruhi motivasi melalui pilihan yang dibuat dengan tujuan yang ditetapkan. Untuk itu siswa diharapkan memiliki efikasi diri dalam mengikuti kegiatan akademik. Efikasi diri akademik didefinisikan sebagai perasaan individu akan kemampuan dirinya dalam mengerjakan tugas akademik, yaitu tugas yang berhubungan dengan ilmu pengetahuan yang harus dipelajari selama individu menempuh pendidikan.

Keyakinan terhadap kemampuan diri dalam melakukan sesuatu (efikasi diri) merupakan sikap yang harus dimiliki oleh siswa. Identifikasi masalah efikasi diri yang rendah yaitu cenderung menghindari tugas, ragu-ragu akan kemampan dirinya, apatis dan tugas yang sulit dianggap sebagai ancaman. Apabila siswa memiliki efikasi diri yang rendah akan memengaruhi dan menghambat proses belajarnya.

Luthans (dalam Permana, Farida dan Budi 2016: 58-59) menjelaskan bahwa ciri-ciri individu yang memiliki efikasi diri rendah yaitu cenderung menghindari tugas, ragu-ragu akan kemampuannya, tugas yang sulit dipandang 
sebagai ancaman, aspirasi dan komitmen pada tugas lemah, tidak berpikir bagaimana menghadapi masalah dan tidak suka mencari situasi yang baru.

Berdasarkan pra penelitian yang dilakukan serta informasi yang didapatkan dari wawancara dengan salah seorang guru di SMP Negeri 3 Sampolawa pada tanggal 10 Agustus 2018 diketahui terdapat fenomena yang terjadi yaitu siswa seringkali merasa tidak meyakini kemampuan dirinya sehingga dia tidak percaya diri ketika maju presentasi, tidak ingin terlibat dalam mengerjakan tugas, tidak mengerjakan tugas, menghindari tugas-tugas yang dirasa sulit, serta ragu dengan kemampuan dirinya. Dari beberapa fenomena yang terjadi, serta wawancara yang telah dilakukan, peneliti menyimpulkan bahwa masalah yang dialami siswa-siswa tersebut adalah masalah efikasi diri siswa sehingga mereka tidak meyakini kemampuan dirinya.

Permasalahan-permasalahan siswa yang berkaitan dengan efikasi diri siswa seperti pada studi awal dapat memberi dampak negatif jika dibiarkan dan akan memengaruhi prestasi belajar siswa sehingga sangat penting perilaku ini agar segera dihilangkan agar tidak membawa dampak yang negatif bagi siswa dan untuk menghilangkan perilaku rendahnya efikasi diri siswa terlebih dahulu harus diketahui faktor-faktor penyebab perilaku tersebut, agar nantinya dapat menghadirkan solusi yang tepat untuk permasalahan efikasi diri Siswa. Dari uraian tersebut, peneliti berniat melakukan penelitian dengan judul "Faktor-faktor Penyebab Rendahnya Efikasi Diri Siswa di SMP Negeri 3 Sampolawa". Adapun tujuan dari penelitian ini adalah untuk mengetahui faktor-faktor penyebab rendahnya efikasi diri pada siswa SMP Negeri 3 Sampolawa.

Feist dan Feist (dalam Amir 2016: 337) menyatakan bahwa faktor faktor yang memengaruhi rendahnya efikasi diri siswa adalah sebagai berikut:

1. Faktor internal

a. Pengalaman menguasai sesuatu (mastery experience)

Pengalaman menguasai sesuatu yaitu performa masa lalu. Secara umum, performa yang berhasil akan meningkatkan efikasi individu sedangkan pengalaman pada kegagalan akan menurunkan efikasi diri. Setelah efikasi diri kuat dan berkembang melalui serangkaian keberhasilan, dampak dari kegagalan-kegagalan umum akan terkurangi dengan sendirinya. Bahkan kegagalan-kegagalan tersebut dapat dikurangi dengan memperkuat motivasi diri apabila seseorang menemukan hambatan yang tersulit terus menerus.

b. Modeling sosial

Pengamatan terhadap keberhasilan orang lain dengan kemampuan yang sebanding dalam mengerjakan suatu tugas akan meningkatkan efikasi diri dalam mengerjakan tugas yang sama. Begitu pula sebaliknya, pengamatan terhadap kegagalan orang lain akan menurunkan penilaian individu mengenai kemampannya dan individu akan mengurangi usaha yang dilakukannya.

c. Persuasi sosial

Individu diarahkan sesuai dengan saran, nasihat dan bimbingan sehingga dapat meningkatkan keyakinan tentang kemampuankemampuan yang dimiliki dapat membantu tercapainya tujuan yang diinginkan. Individu yang diyakinkan secara verbal cenderung akan berusaha dengan keras untuk mencapai suatu keberhasilan. Namun, pengaruh persuasi tidaklah terlalu besar dikarenakan tidak memberikan pengalaman yang dapat langsung dialami atau diamati oleh individu.

d. Kondisi fisik dan emosioal

Emosi yang kuat biasanya akan mengurangi performa saat seseorang mengalami ketakutan yang kuat, kecemasan akut atau tingkat stres yang tinggi, kemungkinan akan memunyai ekspetasi efikasi yang rendah.

2. Faktor Eksternal

a. Budaya

Budaya memengaruhi self-efficacy melalui nilai (value). Kepercayaan (believe), dan proses pengaturan diri (self-regulation process) yang berfungsi sebagai sumber penilaian self-efficacy dan juga sebagai konsekuensi dari keyakinan akan self-efficacy.

b. Jenis kelamin

Perbedaan gender juga berpengaruh terhadap self-efficacy. Hal ini dapat dilihat dari penelitian Bandura (1997) yang menyatakan bahwa wanita efikasinya lebih tinggi dalam mengelola peranannya. Wanita yang memiliki peran selain sebagai ibu rumah tangga, juga sebagai waita karir akan memiliki self-efficacy yang tinggi dibandingkan dengan pria yang bekerja.

c. Sifat dari tugas yang dihadapi

Derajat kompleksitas dari kesulitan tugas yang dihadapi oleh individu akan memengaruhi 
penilaian individu tersebut terhadap kemampuan dirinya sendiri. Semakin kompleks suatu tugas yang dihadapi oleh individu maka akan semakin rendah individu tersebut menilai kemampuanya. Sebaliknya, jika individu dihadapkan pada tugas yang mudah dan sederhana maka akan semakin tinggi individu tersebut menilai kemampuanya.

d. Insentif eksternal

Faktor lain yang dapat memengaruhi selfefficacy individu adalah insentif yang diperolehnya. Bandura (1997) menyatakan bahwa salah satu faktor yang dapat meningkatkan self-efficacy adalah competent contingens incentive, yaitu intensif yang diberikan oleh orang lain yang merefleksikan keberhasilan seseorang.

\section{Metode Penelitian}

Penelitian ini dilaksanakan di SMP Negeri 3 Sampolawa dalam kurun waktu selama tiga (3) bulan yakni sejak bulan Agustus hingga bulan Desember tahun 2018.

Jenis penelitian ini adalah penelitian kualitatif dengan jenis studi kasus yang bertujuan untuk menggambarkan atau mengetahui secara mendalam mengenai faktor-faktor penyebab rendahnya efikasi diri siswa di SMP Negeri 3 Sampolawa.

Peneliti memeroleh informasi dengan melakukan wawancara, yang dimana peneliti melakukan wawancara dengan 1 orang guru, 1 orang wali kelas dan 2 orang siswa.

Analisis data dilakukan menggunakan metode analisis data kualitatif menurut Miles dan Huberman (dalam sugiyono, 2017: 133) yang terdiri dari beberapa tahapan yakni:

1. Data Collection (Pengumpulan Data)

Dalam penelitian ini, pengumpulan data dilakukan dengan cara wawancara mendalam dan dokumentasi.

2. Data Reduction (Reduksi Data)

Reduksi data merupakan proses pemilihan, pemusatan perhatian pada penyederhanaan, pengabsahan, dan transpormasi data "kasar" yang muncul dari catatan-catatan tertulis di lapangan. Dalam reduksi data, peneliti merangkum pokok-pokok data yang diperoleh dari wawancara dan dokumentasi sehingga dapat memberikan gambaran yang jelas tentang faktor-faktor penyebab rendahnya efikasi diri pada siswa SMP Negeri 3 Sampolawa.

\section{Data Display (Penyajian Data)}

Penyajian data merupakan sekumpulan informasi tersusun yang memberi kemungkinan adanya penarikan kesimpulan dan pengambilan tindakan. Melalui penyajian data, data terorganisasi, tersusun dalam pola hubungan sehingga dapat semakin mudah dipahami. Penyajian data ditampilkan dengan sekelompok informasi yang memberi kemungkinan adanya penarikan kesimpulan dan pengambilan tindakan yang mengarah pada tercapainya sebuah tujuan penelitia

4. Data Conclusion Drawing/ Verification (Penarikan Kesimpulan)

Kesimpulan dalam penelitian kualitatif diharapkan merupakan temuan baru yang dapat memberikan deskripsi atau gambaran suatu obyek yang sebelumnya masih remang-remang sehingga setelah diteliti menjadi jelas, dapat berupa hubungan kasual atau interaktif hipotesis atau teori.

Kesimpulan yang dihasilkan dalam penelitian ini diarahkan untuk menjawab seluruh permasalahan penelitian dan memberikan gambaran tentang faktor-faktor penyebab rendahnya efikasi diri siswa SMP Negeri 3 Sampolawa

\section{Hasil Penelitian dan Pembahasan Hasil Penelitian}

Faktor-faktor penyebab rendahnya efikasi diri siswa SMP Negeri 3 Sampolawa terdiri dari faktor internal dan faktor eksternal.

1. Faktor Internal

a. Pengalaman menguasai sesuatu

Faktor pengalaman menguasai sesuatu yang meliputi pengalaman di masa lalu seperti kegagalan yang di masa lalu dapat menyebabkan terjadinya efikasi diri rendah. Pengalaman tersebut secara otomatis akan menjadi pendorong atau penyebab seorang siswa agar tidak berprestasi. Faktor pengalaman menyebabkan siswa tidak memiliki semangat untuk berprestasi sehingga sulit untuk memiliki semangat seperti teman-teman yang lainya.

Berdasarkan informasi yang diperoleh melalui wawancara pada siswa yang menjadi informan dikemukakan bahwa dengan pengalaman yang dialami dengan mengenang atau mengingat masa lalu yang ia alami akan mengalami efikasi diri rendah. Dari hasil wawancara tersebut maka faktor pengalaman 
menguasai sesuatu merupakan faktor penyebab rendahnya efikasi diri siswa.

b. Modeling sosial

Faktor modeling sosial merupakan faktor penyebab yang merujuk pada penglihatan dan tanggapan yang tidak baik sehingga menjadi pendorong untuk tidak berprestasi. Ketika mengamati kegagalan orang lain atau orangorang yang ada didekatnya atau teman-temanya biasanya membuat individu enggan untuk berprestasi.

Siswa SMP Negeri 3 Sampolawa yang memiliki efikasi diri rendah yang tidak percaya diri dengan kemampuan yang ia miliki, ketika melihat orang-orang disekelilingnya gagal maka ia merasa gagal.

\section{Faktor Eksternal}

a. Jenis Kelamin

Faktor jenis kelamin berpengaruh terhadap tingkat efikasi diri siswa karena tingkat pemahaman laki-laki dan perempuan itu berbeda. Tingkat efikasinya lebih tinggi perempuan dibandingkan dengan laki-laki. Berdasarkan informasi yang diperoleh, ditemukan fakta bahwa tingkat efikasi diri seseorang tergantung pada jenis kelamin. Berdasarkan uraian di atas dapat disimpulkan bahwa faktor jenis kelamin bisa ikut berpengaruh terhadap tingkat efikasi diri seseorang.

b. Sifat dari tugas yang dihadapi

Sifat dari tugas yang dihadapi merupakan tingkat kesulitan yang akan memengaruhi tingkat kesulitan tugas yang dihadapi oleh individu akan memengaruhi tingkat efikasi diri seseorang terhadap kemampuan dirinya sendiri. Efikasi diri seseorang tergantung pada tingkat kesulitan yang dihadapi oleh setiap individu. semakin tinggi tingkat kesulitan yang dihadapi maka semakin akan memengaruhi keyakinan dalam dirinya. Berdasarkan informasi yang diperoleh diketahui bahwa banyak siswa yang ketika menghadapi tugas yang sulit itu dapat membuat keyakinannya berubah. Dari uraian di atas dapat disimpulkan bahwa efikasi diri seseorang bisa dipengaruhi oleh sifat dari tugas yang dihadapi

c. Insentif eksternal

Faktor insentif eksternal merupakan salah satu faktor yang dapat menghambat tingkat efikasi diri seseorang, jika siswa mendapat prestasi dan guru tidak memberikan sebuah reward atau hadiah itu bisa dapat memengaruhi tingkat efikasi diri seseorang. Berdasarkan informasi yang diperoleh, terdapat dampak yang sangat baik pada siswa ketika segala perbuatan baik yang mereka lakukan memeroleh reward dari pihak guru atau temantemannya.

\section{Pembahasan}

Efikasi diri adalah keyakinan seorang individu mengenai kemampuannya dalam mengorganisasi dan menyelesaikan suatu tugas yang diperlukan untuk mencapai hasil tertentu. Efikasi diri yakni keyakinan bahwa seseorang bisa menguasai situasi dan mendapatkan hasil positif. (Santrock, 2007) mengatakan bahwa efikasi diri berpengaruh besar terhadap perilaku. Misalnya, seorang murid yang efikasi dirinya rendah mungkin tidak mau berusaha belajar untuk mengerjakan ujian karena tidak percaya bahwa belajar akan bisa membantunya mengerjakan soal.

Alwisol (dalam Adicondro \& Purnamasari 2001: 20) menjelaskan bahwa efikasi diri dapat diperoleh, diubah, ditingkatkan atau diturunkan melalui salah satu atau kombinasi empat sumber, yakni pengalaman menguasai sesuatu prestasi (performance accomplishment), pengalaman vikarius (vicarious experiences), persuasi sosial (social persuation) dan pembangkitan emosi (emotionall physiological states). Efikasi diri yang rendah akan sangat memengaruhi seseorang dalam menyelesaikan tugasnya untuk mencapai hasil tertentu. Hal ini dapat dikaitkan dengan kurangnya informasi tentang kemampuan para siswa untuk yakin pada dirinya sendiri dalam mengerjakan tugas yang diberikan kepada mereka.

Ghufron dan Rini (2014: 77) menjelaskan bahwa efikasi diri secara umum adalah keyakinan seseorang megenai kemampuan-kemmapuannya dalam mengatasi beraneka ragam situasi yang muncul dalam hidupnya. Efikasi diri secara umum tidak berkaitan dengan kecakapan yang dimiliki, tetap berkaitan dengan kayakinan individu mengenai hal yang dapat dilakukan dengan kecakapan yang ia miliki seberapapun besarnya. Efikasi diri akan memengaruhi beberapa aspek dari kognisi dan perilaku seseorang. Oleh karena itu, periaku setiap individu akan berbeda dengan individu yang lain.

Feist (dalam Anggara, Yusuf \& Marjohan 2016: 44), menjelaskan bahwa Efikasi diri bukanlah ekspektasi dari hasil tindakan seseorang, melainkan efikasi diri merujuk kepada keyakinan 
diri seseorang. Betapapun individu menyadari bahwa ada titik kekurangan yang dimiliki, tetapi ia tetap yakin bahwa ia memiliki kemampuan untuk melakukan sesuatu dengan lebih baik, sedangkan ekspektasi atas hasil merujuk kepada adanya prediksi atas kemungkinan-kemungkinan mengenai konsekuensi perilaku tersebut. Efikasi diri merupakan salah satu faktor yang sangat penting dalam membangkitkan kepercayaan dari dalam diri siswa untuk lebih baik lagi dalam mencapai prestasi belajar. Efikasi diri siswa biasanya banyak memengaruhi kondisi siswa dalam kelompok diskusi, mengerjakan tugas dari guru dan prestasi belajar.

Rustika (2012: 18) menyebutkan bahwa efikasi diri memegang peran yang sangat penting dalam kehidupan sehari-hari, seseorang akan mampu menggunakan potensi dirinya secara optimal apabila efikasi diri mendukungnya. Efikasi diri tidak datang dengan sendirinya, tetapi merupakan hasil dari berbagi pengetahuan dan tanggung jawab, hubungan yang beragam, tugastugas yang bermanfaat dan interaksi dengan orang lain. Faktor-faktor penyebab rendahnya efikasi diri siswa SMP Negeri 3 Sampolawa disebabkan oleh berbagai faktor, yaitu faktor internal dan faktor eksternal.

Faktor penyebab rendahnya efikasi diri siswa di SMP Negeri 3 Sampolawa yang pertama adalah faktor pengalaman menguasai sesuatu, faktor pengalaman menguasai sesuatu meliputi pengalaman yang pernah dialami oleh siswa seperti pengalaman yang tidak mengenakan atau pengalaman buruk yang dapat menyebabkan menurunya prestasi belajar siswa sehingga dapat mengakibatkan efikasi dirinya menurun.

Faktor kedua yaitu faktor modeling sosial atau pengamatan tentang keberhasilan orang lain ketika siswa mengamati orang-orang di sekelilingnya atau teman-teman sekolahnya mengalami kegagalan dalam prestasinya maka itu dapat menyebabkan dia berkurang rasa percaya dirinya tentang kemampuan yang ia miliki sehingga menyebabkan efikasi dirinya menurun.

Faktor ketiga yaitu persuasi sosial atau nasihat-nasihat yang diberikan oleh bapak/ ibu guru, ketika siswa mendengarkan arahan-arahan atau nasihat-nasihat dari bapak/ ibu guru itu semua dapat meningkatkan atau dapat membantu tercapainya tujuan yang diinginkan tetapi jika sebaliknya siswa tidak mendengarkan arahanarahan dari bapak/ ibu gurunya siswa akan tidak mencapai tujuan atau bahkan bisa terjadi siswa tersebut akan menurun tingkat efikasi dirinya.

Faktor keempat yaitu kondisi fisik dan emosional atau emosi yang kuat, jika siswa memiliki emosi yang tinggi bisa berdampak pada proses belajarnya atau daya serapnya terhadap mata pelajaran sehingga prestasinya menurun dan berdampak pada efikasi dirinya, jika kondisi emosionalnya tidak stabil itu akan berdampak pada efikasi diri.

\section{Kesimpulan dan Saran \\ Kesimpulan}

Berdasarkan uraian hasil penelitian dan pembahasan dapat disimpulkan bahwa faktorfaktor penyebab rendahnya efikasi diri siswa di SMP Negeri 3 Sampolawa adalah faktor internal yang terdiri atas faktor pengalaman menguasai sesuatu, modeling sosial, persuasi sosial, kondisi fisik dan emosional, serta faktor eksternal yaitu faktor budaya, jenis kelamin, sifat dari tugas yang dihadapi dan insentif eksternal.

\section{Saran}

1. Bagi Kepala Sekolah, harus berupaya selalu mengontrol kegiatan-kegiatan yang dilakukan oleh siswa agar setiap kegiatan yang dilakukan oleh siswa dapat meningkatkan prestasi belajarnya dan tidak terjadi lagi efikasi diri rendah.

2. Bagi Wali kelas, senantiasa mengawasi proses dan segala aktivitas siswa yang dilakukan baik di ruangan kelas maupun di luar ruangan sehingga tidak terjadi lagi efikasi diri rendah.

3. Bagi Guru, dengan mengetahui faktor-faktor penyebab rendahnya efikasi diri siswa guru dapat meneliti masalah yang dialami siswa agar dapat diberikan arahan-arahan atau masukan mengenai efikasi diri.

\section{Daftar Pustaka}

Adicondro, Nobelina dan Alfi Purnamasari. (2011). Efikasi Diri, Dukungan Sosial Keluarga dan Self Regulated Learning Pada Siswa Kelas VIII. Jurnal Humanitas.Vol. VIII, No. 1, Januari 2011.

Alwisol. (2010). Psikologi Kepribadian. Malang: UMM Press.

Bandura, Albert. (2009). Self-efficacy in Changing Societies. New York: Cambridge University Press. 
Bandura, Albert (1997). Self-efficacy: The Exercise of Control. New York: W.H Freeman and Company.

Feist, Jess dan Gregory J., Feist. (2010). Teori Kepribadian. Jakarta: Salemba Humanika.

Ghufron, Nur. \& Rini, R.W. (2012). Teori-Teori Psikologi. Yogyakarta: Ar-Ruzz Media.

Ghufron, Nur dan Risnawati Rini. (2014). TeoriTeori Psikologi. Yogyakarta: Ar-Ruzz Media.

Permana, Hara. dkk. (2016). Hubungan Antara Efikasi Diri dengan Kecemasan dalam Menghadapi Ujian Pada Siswa Kelas IX Mts. Al Hikmah Brebes. Jurnal Hisbah. Vol. 13, No. 1.

Rustika, Made. (2012). Efikasi Diri: Tinjauan Albert Bandura. Jurnal Psikologi. Vol.20, No. 1-2, 2018.

Rokhimah, Siti. (2015). Pengaruh Dukungan Sosial dan Efikasi Diri terhadap Melanjutkan Pendidikan Ke Perguruan Tinggi Pada Siswa SMA Negeri 1 Tenggarong Seberang. Jurnal Psikologi. Vol. 3, No. 1, 2015: 383-394.

Sugiono. (2010). Statistika untuk Penelitian. Bandung: Alfabeta.

Taylor, Shelley E. et al. (2009). Psikologi Sosial Edisi Kedua Belas. Jakarta: Kencana Prenada Media Group. 
